\title{
COVID -19 and its effect on Marketing of Solar Water Heater
}

V. Vardhini, Research Scholar, Bharathiar University, Coimbatore, India

Dr. P. Raja, Director, SIVET College, Gowrivakkam, Chennai, India.

Electronic version

URL: http://www.researchambition.com

DOI: https://doi.org/10.53724/ambition/v5n4.05

ISSN: 2456-0146

Vol. 5, Issue-IV, February 2021

Page No. 15-22

Publisher

Welfare Universe

email: publish2017@gmail.com

OResearch Ambition: An International Multidisciplinary e-Journal 2021. This Open Access article is published under a Creative Commons Attribution Non-Commercial 4.0 International License https://creativecommons.org/licenses/by-nc/4.0/, which permits non-commercial reuse, distribution, and reproduction in any medium, provided the original work is properly cited. For citation use the DOI. For commercial re-use, please contact editor email:- publish2017@gmail.com By accessing the work you hereby accept the Terms. Non-commercial uses of the work are permitted without any further permission from Research Ambition: An International Multidisciplinary eJournal provided the work is properly attributed. 


\section{COVID -19 and its effect on Marketing of Solar Water Heater}

\section{Abstract}

${ }^{*}$ V. Vardhini,

Science, Technology, Inventions, innovations - these are some words which defines the progress and the development of human race. Energy sources like oil, coal and natural gas which humans are using for past many decades are economically feasible but their direct and indirect environmental consequences cannot be unseen. A new thing has emerged 2019 - 20 that we are not able to understand and not able to find the 100\% cure is COVID -19. The whole world is in lockdown mode for last one year. Even though the activities have started post lockdown period, the installation and maintenance activities are not back to the track mainly because of the high dependency on exports from China for solar cells and solar modules. The ban on export activities have impacted the world. Researchers are predicting that SARS-CoV-2 can spread by water and aerosols also after taking reference from Amoy Garden case during SARS-CoV in 2003 and some of them have found the water samples positive for COVID-19 tests. As it is evident from the literature that some viruses are susceptible to high temperature, the same behavior was observed for corona virus so the Integrated Collector Storage (ICS) present in solar water heater system can be used for water heating. It is significant that by increasing the water temperature could reduce the disinfection time.

Keywords - Solare water heater, Covid-19, solar water heater market, Integrated Collector Storage.

\section{Introduction}

Science, Technology, Inventions, innovations - these are some words which defines the progress and the development of human race. But while running forward in the race the humans have forgotten their roots. Human exist because Mother Nature exist. Human is living on Earth because among all planets only Earth is compatible for living. Only Earth's atmosphere is supportive for generating and sustaining a life. But in the name of inventions and development humans are destroying the Earth. Humans are not only destroying the outer layer of Earth but also digging into the Earth and empting all the fuels and minerals which has taken over millions of years to accumulate. By destroying the Ozone layer, the harmful sunrays are penetrating into the Earth and creating a greenhouse effect due to which the temperature of Earth is increasing, due to which ice are melting into sea and sea level is increasing, due to which coastal areas are slowly submerging into the sea. How many of us know that there is a

\footnotetext{
${ }^{*}$ Research Scholar, Bharathiar University, Coimbatore, India.

${ }^{* *}$ Director, SIVET College, Gowrivakkam, Chennai, India.
} 
country name Tuvalu? It is estimated that Tuvalu will be the first country to be submerged into the sea in coming years because of increasing sea level. Likewise, we have almost exhausted the fuels from the Earth which are non-renewable that means it will take another millions of years to produce those fuels. To live in this planet Mother Nature provide us with enough of energies but the greed of human is not satisfied with these energies and tried to exploit our Mother Nature and now it has backfired. Now, humans have only two options, either to live in harmony with the mother nature and using the energies that it provides us like wind energy, hydro energy, solar energy and bio-fuels or to witness our own extinction.

It's high time that we understand the seriousness of the situation and start using more of natural resources and create a sustainable future for our coming generations. Energy sources like oil, coal and natural gas which humans are using for past many decades are economically feasible but their direct and indirect environmental consequences cannot be unseen. These consequences emphasis on the budding need for more effective use of alternative and clean source of energy. There are many natural resources but in this article the concentration is on solar energy and specifically on solar water heater. Solar water heating system refers to the process of providing hot water with the help of solar energy. The first solar water heater was made in back 1891 but the importance and the usage of solar water heater has increased in recent years after the realization that we have to take corrective measures to what we have destroyed. To increase the usage of solar water heater, companies have to penetrate in all markets like urban, rural and have to make it affordable may be with the help of respective country's government. Companies must advertise more about the benefits and importance of the solar water heater.

Humans are scared of unknown, humans are scared of things that they cannot control. A new thing has emerged 2019 - 20 that we are not able to understand and not able to find the $100 \%$ cure is COVID -19. It's a virus which is highly contagious. The whole world is in lockdown mode for last one year. More people have died due to COVID - 19 than many wars. The scientist are still trying to understand this virus and how it spreads and how it reacts differently on different person's body. Vaccinated is created but scientists are not sure that it will work $100 \%$ on everybody.

Now we have a problem COVID -19, can we find a solution or prevention by collaborating with Mother Nature? In this article, we try to review the literature of the researchers where they study how solar water can be used to disinfect the virus.

\section{Solar Water Heater}

Sun is present in our solar system even before there is life in our planet. Energy from sun is the main source of life. By using that energy, we can make our lives more sustainable, we can reduce the amount of pollution. One of the products which uses solar power is Solar Water Heater. And the main advantage is the fuel used in this product is free i.e. sunrays. 
Solar water heater can be very cost-effective way to get hot water for your home. Solar water heater is available in two types - Passive and active.

Active solar water heaters have circulating pumps and controls. Furthermore, the active solar water heater can be classified into direct circulation system and indirect circulation system. Direct circulation system is popular in the areas where the climate does not go under freezing point. Indirect circulation system is popular in the areas where the climate goes under freezing point. In direct circulation system, the pumps circulate household water through the collectors and into the home. In indirect circulation system, pumps circulate a non- freezing, heat transfer fluid through the collector and the heat exchanger. This heats the water and then flows into the home. ${ }^{1}$

Passive solar water heater does not have circulating pumps and controls. Passive solar water heater systems are less expensive than active solar water heater system but they are not as effective. On the brighter side of passive solar water heating system, they are more reliable and may last longer. Passive solar water heating system can be classified into integral -collector storage passive system and thermo syphon systems. Integral collector storage passive system works best in areas where the temperature rarely falls below freezing. In thermo syphon systems, water flows through the system when warm water rises and cool water sinks. For the warm water rise into the tank, the collector must be installed below the storage tank. It is usually more expensive than passive solar water heating system.

Basic parts of solar water heater systems are storage tanks and solar collectors. A well- insulated storage tanks are the basic requirement for most of the solar water heater. For residential applications, three options are available for the solar collectors. Among which appropriate solar collector can be used. They are: - Flat plate collector, Integral collector- storage system, Evacuated tube solar collectors.

Installing an appropriate solar water system is not enough if one does not maintain it properly. Active systems need more maintenance than passive system. There are issues like scaling and corrosion that can happen without proper maintenance. Scaling is one of the biggest problems in solar water heater system. Some domestic water is high in mineral content which are normally known as hard water. Due to hard water, buildup or scaling of minerals mainly calcium deposits in solar water heating systems. Depending on the water conditions one must maintain the solar water heating system. To avoid scaling, one can use water softeners or a mild acidic solution can be circulated through the collector or domestic hot water loop.

\section{Market of Solar Water Heater}

The mechanism of solar water heater is very simple. It converts sunlight into heat with the help of thermal collector in the solar water heater system. Solar water heater system is installed in a place

\footnotetext{
${ }^{1}$ V. Kadambi, "performance of a collector-cum-storage type of solar water heater," vol. 18, pp. 327-335, 1976.
} 
where the sunlight is available for the maximum time generally on the open terrace. There is an insulated storage tank which stores the water that get heated at the day time and it can be used whenever required. Cost effectiveness and reduction of carbon footprint are the few advantages of solar water heater system. Due to the fast depletion of non - renewable resources it's high time that we focus to control our energy consumption. It is one of the main reasons to boost the market of solar water heater system. Many countries Government, NGOs and environmentally conscious people are switching to clean energies like solar energy. Many countries like India, China, US, Italy and other countries have increased their investment to install solar water heaters because according to Environmental Impact Assessment (EIA) solar energy have surpassed biomass energy and have become the third most prevalent renewable electricity source.

The main attraction of solar water heater market is the need for reducing energy bills. Apart from being environmentally friendly and cutting down the $\mathrm{CO} 2$ emissions, the solar power is widely used because it is affordable source of electricity and helps to reduce energy bills.

With the support of government's policies to enable adoption of renewable technologies, it can be projected that global solar water heater market will grow at a high rate mainly because of the increasing demand for replacement of existing water heaters.

Not only India's solar water heater market is expanding, the whole world's solar water heater market is expanding. Global solar water heater market has been segmented based on type, collector type, application, and region.

On the basis of type, the solar water heater market can be classified into pumped and thermo syphon. Among pumped and thermo syphon, thermo syphon is leading the market and has largest market share, mainly because of the low pricing, ease in installation and usage of the product. Another classification is glazed and unglazed and among these types glazed segment has emerged as solar water heater market leader due to high absorption efficiency of glazed collectors compared to unglazed collectors. Although, high price of glazed collectors may restrict the usage for small-scale applications.

Furthermore, the global solar water heater market can be classified into residential, commercial and industrial. Among these, residential segment is estimated to have highest growth rate in the global solar water heater market. The main reason for the residential segment to lead the market is the robust investment in the construction sector for re-establishment and refurbishment of the buildings. Solar collectors are installed on the roof in most of these new buildings which are then connected to the water tank by means of a circulating pump.

Based on capacity, 100 liters capacity segment is having high market share. The reason the 100 liters capacity is leading is increase in demand of solar water heater among residential segment. In a 
residential building for a family of 2-3 members, low cost solar water heater with 100 liters capacity is sufficient. $^{2}$

The growth of the global solar water heater market is driven by the rise in demand for cost effective and eco-friendly energy solutions and different government policies for various rebate and energy schemes. However, the main hindrance in the market growth is the requirement of a huge roof area for a solar water heating system but on the other hand, advancements in energy backup systems present new opportunities in the coming years.

Recently, on 21-22 November 2020, Indian Prime Minister Narendra Modi participates in the $15^{\text {th }}$ G20 summit organized by Saudi Arabia in a virtual format. In his address, PM Modi claimed that India is now focused on achieving its next target of $450 \mathrm{GW}$ of renewable energy capacity by 2030 as India will meet its target of $175 \mathrm{GW}$ capacity well before the target 2022. In the summit, PM Modi emphasized that India has adopted a low carbon and climate - resilient development approach and has been inspired by its traditional ethos of living in harmony with the environment. India is moving forward with the goal of reducing its carbon footprint by 30-35 percent over the coming years. On 15 December 2020, PM Modi have virtually inaugurated the world's largest renewable solar and wind energy park in Gujrat's Kutch.

Not only India but the global solar water heater market is expected to witness substantial growth because of the increase in the demand for cost efficient technology for heating water. By region, Asia Pacific is expected to be the fastest-growing market. This is because of the significant investments in solar power in China, Japan, and India. For instance, to shift its dependence from fossil fuels to renewable fuels to control pollution and maintain ecological balance many countries are introducing extensive changes to its energy policies.

\section{COVID - 19}

The COVID-19 pandemic is also known as the coronavirus pandemic. It is an ongoing pandemic which the whole world is facing of coronavirus disease 2019 (COVID-19) caused by severe acute respiratory syndrome. It was first recognized in December 2019 in Wuhan Province, China. In the earlier days of the COVID-19 pandemic where the virus had spread to two more countries outside China, most of the countries in the world were not particularly worried because they were not aware of the seriousness of COVID - 19. It was the perception that those who had come into contact with the Wuhan seafood market, where the only first case was thought to have occurred which had the highest probability of being infected. The World Health Organization declared the outbreak a Public Health

\footnotetext{
${ }^{2}$ SunTank and O. Smith India Water Products Pvt Ltd Solar Water Heater Market Segmentation-Analysis, Emerging Trends-Opportunities and Consumer-Behavior, Forecast Till 2029 - November 26, 2020 - PRESS RELEASE: Paid content from Wired Release
} 
Emergency of International Concern in January 2020 and declared it as a pandemic in March 2020. As of 21 March 2021, more than 122 million cases have been confirmed and with more than 2.71 million deaths because of COVID-19, making it as one of the deadliest pandemics in history. ${ }^{3}$

The symptoms of COVID-19 are highly variable, it can range from none to life-threatening illness. The virus mainly spreads through the air when people are near to each other. The virus leaves an infected person as they breathe, cough, sneeze, or speak and it enters into another person via their mouth, nose, or eyes. It may also spread through contaminated surfaces. Some people do not show any symptoms but that does not mean that they are not the carrier of infected virus. People can remain infectious for up to two weeks and can spread the virus even though they do not show any symptoms.

Preventive measures are recommended for everyone like social distancing, wearing face masks in public, ventilation and air-filtering, hand washing, covering one's mouth when sneezing or coughing, disinfecting surfaces, and monitoring and self-isolation for people exposed or symptomatic. Around the world the scientists are developing and distributing several vaccines. Since the scientists are not able to find the exact nature of virus and how to constraint it, the current treatments are focusing on the symptoms while scientists are working round the clock to develop therapeutic drugs that prevent the virus. Worldwide Government have responded by implementing lockdowns, restricting the travel within and outside country, authorities have executed workplace hazard controls and closed many facilities. Many places and front line workers like doctors, nurses, and scientists have worked round the clock and exposed themselves to the risk of getting infected to increase testing capacity and trace contacts of the infected.

Since the Great Depression, this pandemic has resulted in significant social and economic disruption, including the largest global recession. ${ }^{4}$ This pandemic has led to widespread supply shortages that has been worsened by panic buying, agricultural disruption and food shortages. Many events have been cancelled or postponed due to this pandemic. Many educational institutions, offices and public areas have been partially or fully closed. Through social media and mass media lots of misinformation has circulated because of which issues of racial and geographic discrimination, health equity and balance between public health imperatives and individual rights has increased. A small brighter side of this pandemic is that emission of pollutants and greenhouse gases have been reduced.

This pandemic is caused by a novel corona virus SARS - CoV-2, which is the newest member of corona virus family that has made three outbreaks in last 18 years, namely, Severe Acute Respiratory Syndrome (SARS-CoV) in 2003, Middle East Respiratory Syndrome (MERS-CoV) in 2012 and now in

\footnotetext{
${ }^{3}$ G. Kampf, D. Todt, S. Pfaender, and E. Steinmann, "Persistence of coronaviruses on inanimate surfaces and their inactivation with biocidal agents,” J. Hosp. Infect., vol. 104, no. 3, pp. 246-251, 2020, doi: 10.1016/j.jhin.2020.01.022

4 "The Great Lockdown: Worst Economic Downturn Since the Great Depression". IMF Blog.
} 
2019 SARS-CoV-2 (COVID- 19). Viruses can be transmitted from both symptomatic and asymptomatic infected persons through different transmission routes that include coughing or sneezing droplets, close contact, and aerosol etc. It is evident from the past studies that viruses are often detected in water and that can lead to various waterborne diseases because of fecal contamination, industrial, domestic, hospital and animal wastes in water bodies. Researchers are predicting that SARS-CoV-2 can spread by water and aerosols also after taking reference from Amoy Garden case during SARS-CoV in 2003 and some of them have found the water samples positive for COVID-19 tests. ${ }^{5}$ In some of the most polluted countries in the world it is found that high concentration of bio - aerosols, volatile organic compounds (VOCs) and other air pollutants are also worsening the spread of COVID-19. This could be more dangerous as compared to other transmission routes.

\section{Covid-19 Scenario Affecting Market of Solar Water Heater}

Due to the lockdown, manufacturing activities have been hindered, that has led to shortage of raw materials and manpower. Furthermore, the supply chain has also been disrupted. Because of the lockdown measures and workforce shortage, the installation and maintenance activities have been postponed. Even though the activities have started post lockdown period, the installation and maintenance activities are not back to the track mainly because of the high dependency on exports from China for solar cells and solar modules. The ban on export activities have impacted the world. The manufacturing activities are highly affected because India imports nearly $80 \%$ of its solar cells and modules from China.

\section{Proposed Solar Energy Systems for Inactivation of Covid-19}

Solar energy is a good source of UV and other radiations, that can be used for air purification against micro-organisms and other pollutants by using different mechanisms. As it is evident from the literature that some viruses are susceptible to high temperature, the same behavior was observed for corona virus so the Integrated Collector Storage (ICS) present in solar water heater system can be used for water heating. Heating is an effective physical mechanism to inactivate the viruses that destroys the RNA of viruses. ${ }^{6}$ Some researchers have predicted the traces of SARS-CoV-2. It has become significant to inactivate the viruses to reduce the number of COVID-19 patients. It is significant that by increasing the water temperature could reduce the disinfection time. A study revealed that by incubation at $80^{\circ} \mathrm{C}$ for 5 minutes the Hepatitis - $\mathrm{C}$ virus can be inactivated and the same is predicted for SARS-CoV-2. Therefore, an effective water heating system with good capacity is required. ICS is a kind of water heater that converts the solar energy to heat water, it also reduces the heat loss because of the integrated system. As

\footnotetext{
${ }^{5}$ P. M. Gundy, C. P. Gerba, and I. L. Pepper, "Survival of Coronaviruses in Water and Wastewater," Food Environ. Virol., vol. 1, no. 1, pp. 10-14, 2009, doi: 10.1007/s12560-008-9001-6.

${ }^{6}$ R. Singh, I. J. Lazarus, and M. Souliotis, "Recent developments in integrated collector storage (ICS) solar water heaters: A review,” Renew. Sustain. Energy Rev., vol. 54, pp. 270-298, 2016, doi: 10.1016/j.rser.2015.10.006.
} 
compared to conventional Flat Plate Thermosiphon (FPT) water heaters, the solar to heat conversion rate in ICS systems are good. ICS systems are generally designed for domestic purpose water capacity (100200 litres).

\section{Conclusion}

Right now, when it is a high time that we switch over to natural resources than the non-renewable resources. Natural resources are clean and sustainable. We have to save our planet for our future generations to come. That's our responsibility, that's our legacy. Everyone must be more environmental conscious and use more green energy products. Being environmental conscious is not enough to buy a green product, that product should also be beneficial for the user other than just environmentally friendly. Solar water heater is both environmentally friendly at the same time beneficial for the user. It not only uses the natural resources, it also reduces the electricity bill and provides hot water for a longer time. Government is encouraging to install the solar water heater. It has become mandatory to install solar water heater in commercial buildings, hotels and hospitals. Government is also encouraging to install in residential area by giving many subsidies.

COVID-19 is said to be the one of the deadliest viruses which has caused more deaths than world war. All the countries around the world are struggling to contain this virus. It has been researched that if we increase the temperature then we can control the virus. So on one hand we have i.e COVID-19 and on the other hand i.e Integral Collector Storage (ICS) in solar water heater. We can use the ICS Solar water heater to fight with COVID-19. Government should make it mandatory to install solar water heater in all the construction of new residential houses and also in the existing houses. Government, NGOs and companies should come together to create awareness among public regarding solar water heater. Solar water heater should be affordable for all the classes of the society.

\footnotetext{
$* * * * * * * * * * * * * * * * * * * * * * * *$
} 